\title{
PENGARUH LAMANYA DIABETES MELITUS TERHADAP TERJADINYA DISFUNGSI EREKSI
}

\author{
${ }^{1}$ Natasya J. Dodie \\ ${ }^{2}$ Lydia Tendean \\ ${ }^{2}$ Benny Wantouw \\ ${ }^{1}$ Kandidat Skripsi Fakultas Kedokteran Universitas Sam Ratulangi Manado \\ ${ }^{2}$ Bagian Biologi Fakultas Kedokteran Universitas Sam Ratulangi Manado \\ Email: natasya_dodie@yahoo.com
}

\begin{abstract}
Diabetes mellitus is a condition with excess glucose in the blood which can lead to complications such as chronic diseases, among others cardiovascular disease and sexual dysfunction such as erectile dysfunction. This study aimed to determine the effect of duration of diabetes mellitus on the occurrence of erectile dysfunction. This was an analytic survey with cross sectional study design. Samples were 30 respondents, taken by simple random sampling. Data were collected by using a questionnaire IIEF-5 (International Index of Erectile Function) and the data were univariate analyzed. The results showed that there were 20 people suffered from erectile dysfunction out of 30 respondents. The univariate analysis showed that erectile dysfunction respondents that had diabetes mellitus for 1-4 years were 11 people (36.7\%); and that had diabetes mellitus for 5-8 years were 19 people (63.3\%). The statistical parametric test T-Test found a significant relationship between the duration of diabetes mellitus and erectile dysfunction with $P=0.025$ (a significance level of 0.05). Conclusion: Long duration of diabetes mellitus can lead to erectile dysfunction.
\end{abstract}

Keywords: diabetes mellitus, erectile dysfunction.

\begin{abstract}
Abstrak: Diabetes melitus adalah suatu keadaan dimana terdapat kadar gula berlebihan dalam darah yang dapat mengakibatkan komplikasi berupa penyakit-penyakit kronis seperti penyakit kardiovaskuler dan disfungsi seksual, salah satunya disfungsi ereksi. Penelitian ini bertujuan untuk mengetahui pengaruh lamanya diabetes melitus terhadap terjadinya disfungsi ereksi. Penelitian ini bersifat survei analitik dengan desain penelitian cross sectional. Sampel berjumlah 30 orang yang diambil secara simple random sampling. Data dikumpulkan dengan menggunakan kuesioner IIEF-5 (International Index of Erectile Function) dan data dianalisis secara univariat. Dari penelitian ini didapatkan 20 orang dengan kejadian disfungsi ereksi pada penderita diabetes melitus dari 30 orang responden. Analisa univariat menunjukkan bahwa responden yang mengalami disfungsi ereksi pada pria dengan diabetes melitus selama 1-4 tahun berjumlah 11 orang (36,7\%), dan dengan diabetes melitus selama 5-8 tahun berjumlah 19 orang (63,3\%). Uji parametrik T-Test memperlihatkan terdapat hubungan bermakna antara diabetes melitus yang lama dengan terjadinya disfungsi ereksi dengan nilai $P=0,025$ dengan tingkat signifikansi 0,05. Simpulan: Diabetes melitus yang lama bisa mengakibatkan terjadinya disfungsi ereksi.
\end{abstract}

Kata kunci: diabetes melitus, disfungsi ereksi.

Diabetes melitus merupakan suatu kelompok penyakit metabolik dengan karakteristik hiperglikemia yang terjadi karena kelainan sekresi insulin, kerja insulin atau kedua-duanya. ${ }^{1}$ Diantara penyakit degeneratif, diabetes melitus merupakan salah satu di antara penyakit tidak menular yang akan meningkat jumlahnya dimasa 
yang akan datang. Diabetes melitus sudah merupakan salah satu ancaman utama bagi kesehatan umat manusia pada abad $21 .{ }^{1}$ Perkiraan pada tahun 2000 jumlah pengidap diabetes melitus diatas umur 20 tahun berjumlah 150 juta orang dan dalam kurun waktu 25 tahun kemudian, pada tahun 2025, jumlah itu akan membengkak menjadi 300 juta orang. Meningkatnya prevalensi diabetes melitus di negara berkembang diakibatkan oleh perubahan gaya hidup. ${ }^{1}$

Terdapat dua tipe utama diabetes melitus yaitu, diabetes melitus tipe 1 yang disebabkan kurangnya sekresi insulin dan diabetes melitus tipe 2 yang disebabkan oleh penurunan sensitivitas jaringan target terhadap efek metabolik insulin. Penurunan sensitivitas terhadap insulin ini seringkali disebut sebagai resistensi insulin. ${ }^{2}$ Terdapat juga diabetes melitus tipe lain yaitu karena kelainan genetik, penyakit pankreas, obat, infeksi, antibodi, sindroma seperti cushing syndrome, serta diabetes melitus pada masa kehamilan (diabetes gestasional). ${ }^{3}$ Penyakit diabetes melitus merupakan penyakit yang sering dijumpai dimasyarakat terutama dikalangan masyarakat perkotaan. ${ }^{4}$

Pada penderita diabetes melitus yang sudah lama yaitu lebih dari 5 tahun dan tidak terkontrolnya gula darah akan terjadi gangguan pada sel-sel saraf dan pembuluh darah kecil (mikrovaskular) serta pembuluh darah besar (makrovaskular) kerusakan pada masing-masing pembuluh darah tersebut menimbulkan dampak yang berbeda. Kerusakan pada pembuluh darah kecil terjadi pada mata, ginjal dan saraf. Sedangkan kerusakan pada pembuluh darah besar dapat mempercepat terjadinya aterosklerosis. ${ }^{5}$ Diabetes melitus dapat menimbulkan komplikasi akut seperti hipoglikemia dan ketoasidosis diabetika sedangkan komplikasi kronis berupa makroangiopati, mikroangiopati, dan neuropati. Komplikasi kronis ini biasanya terjadi pada penderita diabetes melitus yang tidak terkontrol. ${ }^{6}$ Diabetes melitus disebutkan juga dapat menyebabkan terjadinya disfungsi ereksi. ${ }^{7}$ Jika penyakit ini terus berlanjut hingga bersifat kronis maka dapat menimbulkan komplikasi seperti gangguan psikologis dan disfungsi seksual khususnya pada pria. ${ }^{8}$

Disfungsi ereksi didefinisikan sebagai ketidakmampuan yang konsisten untuk mendapatkan atau mempertahankan ereksi untuk memuaskan hubungan seksual. ${ }^{9}$ Ereksi terjadi sebagai efek hidrolik karena darah yang masuk dan yang dipertahankan dalam tubuh jaringan spons dalam penis. Proses ini paling sering dimulai sebagai hasil dari gairah seksual, ketika sinyal tersebut dikirimkan dari otak ke saraf di penis. ${ }^{10}$

Adapun faktor-faktor yang juga dapat menyebabkan disfungsi ereksi pada pria dapat dibagi dua yaitu faktor psikis dan organ. Penyebab faktor psikis dilatarbelakangi oleh faktor kejenuhan, kekecewaan, hilangnya daya tarik terhadap pasangan, dan trauma seksual. Untuk fakor organ seperti kelainan pembuluh darah, kelainan persarafan yang terkait dengan penyakit seperti diabetes melitus, hipertensi, dan penyempitan pembuluh darah. Faktor usia juga dapat mempengaruhi resiko terjadinya disfungsi ereksi. ${ }^{11,12}$

Tujuan penelitian ialah untuk mengetahui pengaruh lamanya diabetes melitus terhadap terjadinya disfungsi ereksi, untuk mengetahui mekanisme diabetes melitus yang lama dapat mengakibatkan terjadinya disfungsi ereksi.

\section{METODE}

Penelitian dilakukan di Poli Endokrin BLU RSUP Prof. dr. R. D. Kandou Malalayang, Manado dari bulan November 2012-Januari 2013. Penelitian ini menggunakan survey analitik dengan pendekatan cross sectional. Populasi dalam penelitian ini ialah seluruh penderita pria diabetes melitus. Sebagai bahan penelitiann utama ialah kuesioner dari IIEF-5 yang merupakan standar untuk menilai disfungsi ereksi. Sampel yang digunakan sebesar 30 penderita. Data diambil dari hasil kuesioner yang diisi langsung oleh penderita diabetes melitus. Semua data yang diperoleh diolah dengan menggunakan SPSS dan disajikan dalam bentuk tabel distribusi frekuensi. 
1122 Jurnal e-Biomedik (eBM), Volume 1, Nomor 3, November 2013, hlm. 1120-1125

\section{HASIL}

Hasil pengumpulan data pasien yang berobat di Poli Endokrin RSUP Prof. dr. R. D. Kandou Malalayang dengan jumlah pasien 58 pasien.

\section{BAHASAN}

Diabetes melitus merupakan penyakit kronis yang dapat mengakibatkan kelainan medis, psikologis dan berbagai disfungsi seksual pada pria jika tidak dikelola dengan baik. $^{7}$ Pada Tabel 1 menunjukkan bahwa dari 30 sampel penderita diabetes melitus

\section{KARAKTERISTIK SAMPEL}

Tabel 1. Distribusi sampel berdasarkan umur dengan lamanya mengidap Diabetes Melitus (DM)

\begin{tabular}{|c|c|c|c|c|c|c|}
\hline \multirow{2}{*}{ Umur } & \multicolumn{4}{|c|}{ Lamanya mengidap DM } & \multirow{2}{*}{ Total } & \multirow{2}{*}{$\%$} \\
\hline & 1-4 tahun & $\%$ & 5-8 tahun & $\%$ & & \\
\hline $40-50$ & 4 & $13,3 \%$ & 3 & $10 \%$ & 7 & $23,3 \%$ \\
\hline $51-60$ & 7 & $23,4 \%$ & 16 & $53,3 \%$ & 23 & $76,7 \%$ \\
\hline Total & 11 & $36,7 \%$ & 19 & $63,3 \%$ & 30 & $100 \%$ \\
\hline
\end{tabular}

Tabel 2. Distribusi sampel pria Diabetes Melitus (DM) yang lama dengan Disfungsi Ereksi (DE) Berdasarkan Kategori Umur

\begin{tabular}{|c|c|c|c|c|c|c|}
\hline \multirow[b]{2}{*}{ Umur } & \multicolumn{4}{|c|}{ Disfungsi Ereksi } & \multirow[b]{2}{*}{ Total } & \multirow[b]{2}{*}{$\%$} \\
\hline & Ringan & $\%$ & $\begin{array}{c}\text { Ringan- } \\
\text { sedang }\end{array}$ & $\%$ & & \\
\hline $40-50$ & 4 & $13,3 \%$ & 3 & $10 \%$ & 7 & $23,3 \%$ \\
\hline $51-60$ & 7 & $23,4 \%$ & 16 & $53,3 \%$ & 23 & $76,7 \%$ \\
\hline Total & 11 & $36,7 \%$ & 19 & $63,3 \%$ & 30 & $100 \%$ \\
\hline
\end{tabular}

Tabel 3. Distribusi sampel berdasarkan kebiasaan merokok dengan kejadian Disfungsi Ereksi pada pria Diabetes Melitus

\begin{tabular}{lcccc}
\hline \multirow{2}{*}{ Disfungsi Ereksi } & \multicolumn{3}{c}{ Merokok } & \multirow{2}{*}{ Total } \\
\cline { 2 - 4 } & Ya & Tidak & 10 \\
\hline Ringan & 7 & 3 & $33.3 \%$ \\
$\%$ & $23.3 \%$ & $10 \%$ & 20 \\
Ringan-sedang & 6 & 14 & $66.7 \%$ \\
$\%$ & $20.0 \%$ & $46.7 \%$ & 30 \\
\multicolumn{2}{c}{ Total } & 13 & 17 & $100 \%$ \\
\hline \multicolumn{2}{c}{$\%$} & $43.3 \%$ & $56.7 \%$ & \\
\hline
\end{tabular}

Tabel 4. Distribusi sampel pria Diabetes Melitus yang lama dengan Disfungsi Ereksi

\begin{tabular}{|c|c|c|c|c|c|c|}
\hline \multirow{2}{*}{ Lama } & \multicolumn{4}{|c|}{ Disfungsi Ereksi } & \multirow{2}{*}{ Total } & \multirow{2}{*}{$\%$} \\
\hline & Ringan & $\%$ & Ringan-Sedang & $\%$ & & \\
\hline $1-4$ & 9 & $30 \%$ & 2 & $6.7 \%$ & 11 & $36.7 \%$ \\
\hline $5-8$ & 1 & 3.35 & 18 & $60 \%$ & 19 & $63.3 \%$ \\
\hline Total & 10 & $33.3 \%$ & 20 & $66.7 \%$ & 30 & $100 \%$ \\
\hline
\end{tabular}


terdapat 23 sampel (76,7\%) dengan kategori umur 51-60 tahun yang terbanyak mengalami disfungsi ereksi. Dari hasil penelitian sebelumnya didapatkan bahwa seiring dengan bertambahnya usia terjadinya disfungsi ereksi akan semakin meningkat. Pria usia lanjut pada dasarnya rentan mengalami disfungsi ereksi, hal ini disebabkan karena telah terjadi penurunan jumlah sel otot polos korpus kavernosum yang justru sangat diperlukan bagi mekanisme terjadinya ereksi. Dan juga terjadi sensitivitas pada penis sehingga lebih lama bagi seorang pria untuk mencapai ereksi, kekuatan orgasme, volume ejakulasi, dan frekuensi kegiatan seksual. Selain itu, pada usia lanjut sering terjadi kelainan atau penyakit serta penurunan kadar hormon testosteron yang dapat mengakibatkan disfungsi ereksi. Pada hasil penelitian ini terdapat hubungan bermakna antara usia dan terjadinya disfungsi ereksi yaitu semakin tua usia makin buruk fungsi ereksi. ${ }^{13,14}$

Pada tabel IV.3 berdasarkan kebiasaan merokok dapat dilihat bahwa disfungsi ereksi dengan kategori ringan terjadi pada pria yang merokok yaitu sebanyak 7 orang (23,3\%) dan yang tidak merokok yaitu sebanyak 3 orang (10\%). Sedangkan pada disfungsi ereksi dengan kategori ringansedang terjadi pada pria yang merokok yaitu sebanyak 6 orang $(20,0 \%)$ dan yang tidak merokok yaitu sebanyak 14 orang (46,7\%). Dari kebiasaan merokok tidak didapatkan hubungan bermakna dari hasil penelitian ini. Karena, dari 30 sampel dengan kategori ringan dan ringan-sedang, terdapat 13 orang $(43,3 \%)$ yang merokok dan 17 orang $(56,7 \%)$ yang tidak merokok. Suatu studi mengatakan bahwa pada pria yang merokok satu pak rokok / hari beresiko 24\% lebih tinggi menderita gangguan ereksi dan semakin banyak mereka merokok maka persentase resikonya juga meningkat. ${ }^{15}$ Pada tabel IV.3 didapatkan pria yang tidak merokok mengalami disfungsi ereksi. Data ini menggambarkan kebiasaan merokoknya pada waktu sekarang, dahulu mereka memiliki riwayat merokok dan sekarang sudah menghentikan kebiasaan merokoknya. Merokok juga bisa menjadi penyebab terjadinya disfungsi seksual pada pria terutama ejakulasi dan disfungsi ereksi. Pada pria perokok berusia 40 tahun, lebih sering mengalami gangguan ereksi daripada pria berusia lebih dari 40 tahun tetapi tidak merokok. Bahkan resikonya sampai dua kali lipat pada pria perokok berusia 40 tahun dibandingkan para pria berusia 50 tahun yang tidak merokok. Hal ini disebabkan karena pada saat seseorang merokok, rokok tersebut melepaskan nikotin dan vasokonstriktor (penghalang pembuluh darah) lain yang dapat menghambat aliran pembuluh darah di penis. ${ }^{15}$

Pada tabel IV.4 dilaporkan dari 30 sampel pria diabetes melitus didapatkan hasil bahwa diabetes melitus yang lamanya 1-4 tahun dengan kategori disfungsi ereksi ringan sebanyak 9 orang (30\%) dan pada kategori disfungsi ereksi ringan-sedang sebanyak 2 orang $(6,7 \%)$. Sedangkan pada diabetes melitus yang lamanya 5-8 tahun dengan kategori disfungsi ereksi ringan sebanyak 1 orang $(3,3 \%)$ dan pada kategori disfungsi ereksi ringan-sedang sebanyak 18 orang (60\%).

Penelitian ini didapatkan bahwa diabetes melitus yang lama berhubungan dengan kejadian disfungsi ereksi. Kebanyakan disfungsi ereksi dialami pada penderita yang telah mengidap diabetes melitus lebih dari 5 tahun. Pada diabetes melitus yang lama dapat terjadi kelebihan gula darah atau gula darah yang tidak terkontrol, hal ini disebabkan karena ketidaksadaran dari pasien atau keterlambatan diagnosis karena kebanyakan pasien akan datang mencari pertolongan dari tenaga medis apabila penyakit mereka sudah parah. Sebagian dari orang-orang akan menyadarinya ketika sudah mengalami penurunan berat badan secara tiba-tiba dan beberapa gejala lainnya. Akibatnya gula darah dalam tubuh yang tidak terkontrol dapat merusak sel-sel saraf dan pembuluh darah. ${ }^{16}$ Kerusakan ini diakibatkan adanya stress oxidative pada endotel akibat tingginya gula darah. Endotel dalam keadaan normal bisa menghasilkan nitric oxide (NO) yang berguna untuk melebarkan pembuluh darah termasuk pembuluh darah di penis. Dalam keadaan 
rusaknya pembuluh darah, nitric oxide (NO) tidak dihasilkan sehingga pembuluh darah penis sulit melebar sehingga aliran darah ke organ erektil berkurang sehingga terjadilah disfungsi ereksi. ${ }^{17}$

Lamanya diabetes melitus dan komplikasi mikrovaskuler lainnya (retinopati, neuropati, dan nefropati) merupakan prediktor terjadinya disfungsi ereksi. Disfungsi saraf somatik dan otonom muncul dalam persentase besar pada individu dengan diabetes melitus terkait disfungsi ereksi. Komplikasi makrovaskuler selama diabetes melitus berkontribusi pada pengembangan disfungsi ereksi. Penyakit aterosklerosis pembuluh darah arteri penis hadir dalam $70-80 \%$ kasus dengan disfungsi ereksi. Oklusi arteri kavernosus bisa menjadi faktor yang berkontribusi dalam jangka panjang. Namun, studi terbaru menunjukkan bahwa perubahan struktur dalam pembuluh darah arteri penis saat tidur bisa ada bahkan dalam kasus-kasus dengan disfungsi ereksi tanpa penyakit jantung koroner. $^{18}$

\section{SIMPULAN}

Berdasarkan penelitian yang dilakukan telah didapatkan hasil bahwa lamanya diabetes melitus dapat mengakibatkan terjadinya disfungsi ereksi.

Lamanya diabetes melitus dapat mengakibatkan komplikasi berupa makroangiopati dan mikroangiopati, hal inilah yang mengakibatkan proses ereksi terganggu atau dikenal dengan disfungsi ereksi.

\section{SARAN}

\begin{tabular}{l}
\multicolumn{1}{c}{ Perlu dilakukan edukasi terhadap } \\
penderita diabetes melitus r serta \\
memperbaiki gaya hidup untuk mencegah \\
komplikasi seperti disfungsi ereksi.
\end{tabular}

Serta dapat dilakukan penelitian selanjutnya dengan sampel yang lebih banyak dan pemeriksaan laboratorium yang lengkap.

\section{UCAPAN TERIMA KASIH}

Doitujukan kepada Prof. dr. Edwin de Queljoe, MSc, SpAnd dan dr Luciana Setiawati, MMed dan juga semua pihak yang secara langsung dan tidak langsung telah menumbuhkan ide dan gagasan pada penulis.

\section{DAFTAR PUSTAKA}

1. Purnamasari D. Diagnosis dan Klasifikasi Diabete Melitus. Dalam: Sudoyo AW, Setiyohadi B, Alwi I, Marcellus S K, Siti Setiati, editor. Buku Ajar Ilmu Penyakit Dalam. Jilid 3 Edisi 5. Jakarta: Interna Publishing; 2009.hal: 1880.

2. Guyton AC, Hall EJ. Insulin, Glukoagon dan Diabetes Melitus. Buku ajar Fisiologi Kedokteran. Alih Bahasa: Irawati, Ramadhani D, Dany F, Nuryanto I, Rianti SSP dkk. Jakarta: Penerbit Buku Kedokteran EGC; 2007.hal: 1022.

3. http://usupress.usu.ac.id/files/PenyakitPenyakit\%20yang\%20Memengaruhi\%20Ke hamilan\%20dan\%20Persalinan\%20Edisi\%2 0Kedua_Normal_bab\%201.pdf di akses tanggal 28 oktober 2012.

4. Suyono S. Diabetes Melitus Di Indonesia. Dalam: Sudoyo AW, Setiyohadi B, Alwi I, Marcellus S K, Siti Setiati, editor. Buku Ajar Ilmu Penyakit Dalam. Jilid 3 Edisi 5. Jakarta: Interna Publishing; 2009.hal:1874.

5. 28 juli 2011. http://majalahkesehatan. com/komplikasi-diabetes-mellitus-dalamjangka-panjang/ di akses tanggal 30 januari 2013.

6. 25 september 2010. http://doktermedis.blogspot.com/2010/09/komplikasidiabetes-mellitus-dm.html di akses tanggal 30 november 2012.

7. Suryono, Badrushshalih M. Andropause (menopause pada laki-laki) plus penyakit pada lansia. Jogjakarta. Juni 2010. Hal: 96.

8. Owiredu W, Amidu N, Alidu H, Sarpong C, Gyasi-Sarpong CK. Determinants of Sexual Dysfunction among clinically diagnosed diabetic patients, Reproductive Biology and Endocrinology. 2011, 9-70. http://www.rbej.com/content/pdf/1477- 
7827-9-70.pdf diakses tanggal 28 oktober 2012.

9. Bivalacqua TJ, Usta MF, Champion HC, Kadowitz PJ, Hellstrom WJG. Endothelial Dysfunction in Erectile Dysfunction; Role of the Endothelium in Erectile Physiology and Disease, Journal of Andrology, Vol 24, no. 6. 2003. http://www.andrologyjournal. org/cgi/reprint/24/6_suppl/S17?maxtoshow $=\&$ hits $=10 \&$ RESULTFORMAT $=1 \&$ title $=\mathrm{er}$ ectile+dysfunction\&andorexacttitle=and\&an dorexacttitleabs $=$ and\&andorexactfulltext $=\mathrm{an}$ $\mathrm{d} \&$ searchid=1\&FIRSTINDEX $=0$ \&sortspec $=$ relevance $\&$ tdate $=10 / 31 / 2012 \&$ resourcetyp $\mathrm{e}=$ HWCIT. diakses tanggal 28 oktober 2012.

10. http://www.impotensi.org/2011_04_01_arch ive.html diakses tanggal 28 oktober 2012.

11. Familia D. Seluk-beluk dan fakta Disfungsi Seksual yang wajib Anda ketahui. Jogjakarta: A *Plus Books; 2010.hal 42.

12. 2007-2008.

http://seks.klikdokter.com/subpage.php?id= 1\&sub=26 di akses tanggal 31 januari 2013.
13. Keluarga Berencana.com. Arsip Disfungsi Ereksi. 2007. http://keluargaberencana.com/kesrepro/seks ualitas/disfungsi-ereksi/

14. Lue T, Giuliano F, Khoury S, Rosen R. Clinical manual of sexual medicine sexual dysfunction in men; 2004.p.24.

15. Publishing D. Kupas Tuntas Impotensi dan Ejakulasi Dini. Jogjakarta; 2010. Hal 50-51.

16. Benarkah Diabetes Sebabkan Disfungsi Ereksi? Hidup Sehat Tanpa Diabetes. .http://sehattanpadiabetes.blogspot.com/201 2/07/benarkah-diabetes-sebabkan-disfungsiereksi.html diakses tanggal 14 januari 2013.

17. Sulaifi MF. Disfungsi ereksi dan kencing manis. 30

Desember 2009.http://sulaifi.wordpress.com/2009/12/3 0/disfungsi-ereksi-de-dan-kencing-manis/ diakses tanggal 28 oktober 2012.

18. Díaz-Díaz E, LeónMC, Arzuaga NO, Timossi CM, Díaz RAG, Salinas CA, Larrea F. Erectile Dysfunction: A Chronic Complication of the Diabetes Mellitus. Intecophen; 2012.p.70-5. B Bb 